\title{
Observation of Arboreal Behavior in the Malayan Pitviper (Calloselasma rhodostoma)
}

Rupert J. Grassby-Lewis ${ }^{1}$ and Steven J. R. Allain ${ }^{2}$

149 Colfe Road, Forest Hill, London, SE23 2ES, UK (rupertjordangl@gmail.com)

${ }^{2} 11$ Trafalgar Way, Braintree, Essex, CM7 9UX, UK (steveallain@live.co.uk)

$\mathrm{T}$ he Malayan Pitviper (Calloselasma rhodostoma) is well known for its terrestrial ecology, spending much of its time deep in leaf litter or undergrowth and frequently not moving for days on end (Daltry et al. 1998). An ambush predator that displays feeding mimicry, which is typically seen in young individuals (Schuett 1984), has little need to journey long distances or climb in search of prey. Herein we record an instance of arboreal activity in $C$. rhodostoma, which we believe is novel.

The Khanom District, Nakhon Si Thammerat Province, southern peninsular Thailand, supports a healthy population of Calloselasma rhodostoma. The cryptic nature of this species renders individuals difficult to locate within natural habitat (Looareesuwan et al. 1988) and most encounters are of snakes crossing roads. We had already sighted two of these snakes when, at $2122 \mathrm{~h}$ on 13 June 2013, while walking along the road and checking appropriate vegetation on the bank, we noticed a gravid female measuring approximately $70 \mathrm{~cm}$ in total length perched along a barbed-wire fence approximately $1 \mathrm{~m}$ above the ground (Fig. 1). When disturbed, it appeared to be searching for a safe route to the ground. It used its tail to both grip and balance while traversing the thin wire, similar to how the prehensile tails of arboreal vipers are utilized. After coiling around a concrete pillar, it extended its head toward the ground before dropping off the wire and moving into the undergrowth.

One possible explanation for why the snake climbed the fence was that it was attempting to escape a predator or another perceived threat. Climbing is a known flight response in snakes, even in those species that are primarily terrestrial (Brown and Shine 2004). The proximity to a road might also have come into play as a car or motorbike could have frightened the snake into an unusual flight response. A more typical response would involve a snake fleeing and attempting to
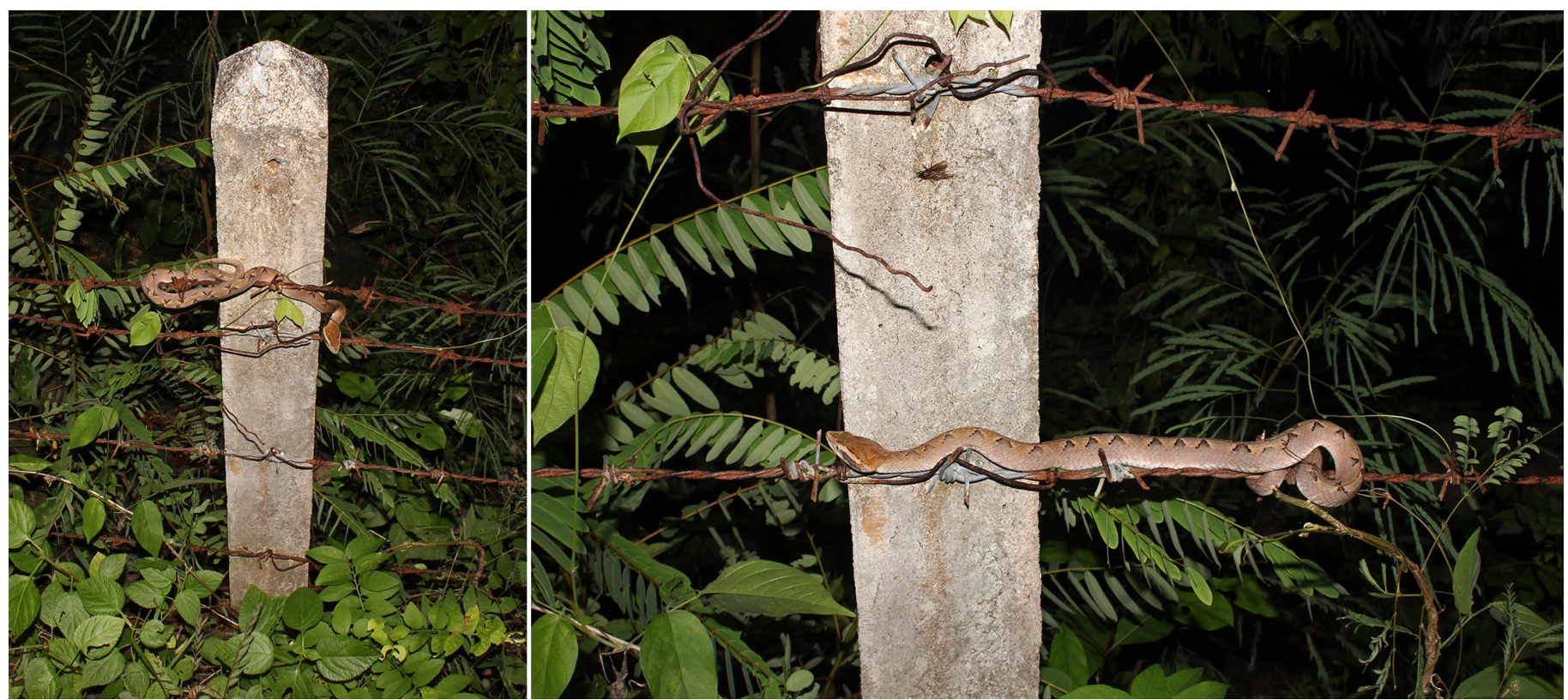

Fig. 1. A gravid female Malayan Pitviper (Calloselasma rhodostoma) approximately $1 \mathrm{~m}$ above the ground on a barbed-wire fence (left) using its tail to grip the wire (right) in a fashion similar to the use of prehensile tails by arboreal pitvipers. Photographs by Rupert J. Grassby-Lewis. 
conceal itself in ground debris (Daltry et al. 1998), but with minimal leaf litter or debris on a concrete road, the likelihood of a snake exhibiting an atypical reaction would appear higher.

\section{Literature Cited}

Brown, G.P. and R. Shine. 2004. Effects of reproduction on the antipredator tactics of snakes (Tropidonophis mairii, Colubridae). Behavioral Ecology and Sociobiology

$$
\text { 56: } 257-262 .
$$

Daltry, J.C., T. Ross, R.S. Thorpe, and W. Wüster. 1998. Evidence that humidity influences snake activity patterns: a field study of the Malayan pit viper Calloselasma rhodostoma. Ecography 21: 25-34.

Looareesuwan, S., C. Viravan, and D.A. Warrell. 1988. Factors contributing to fatal snake bite in the rural tropics: analysis of 46 cases in Thailand. Transactions of the Royal Society of Tropical Medicine and Hygiene 82: 930-934.

Schuett, G.W. 1984. Calloselasma rhodostoma (Malayan pit viper). Feeding mimicry. Herpetological Review 15: 112. 